\title{
Lapatinib, trastuzumab or the combination added to neoadjuvant chemotherapy for breast cancer
}

\author{
Quan Liang1, Qiang Fu', Wei Li², Jiacong You ${ }^{3}$ and Zhanchao Zhao' \\ ${ }^{1}$ Department of General Surgery; ${ }^{2}$ Department of Ultrasonography; ${ }^{3}$ Tianjin Lung Cancer Institute, Tianjin Key \\ Laboratory of Lung Cancer Metastasis and Tumor Microenvironment, Tianjin Medical University General Hospital, \\ 154 Anshan Road, Heping District, Tianjin 300-052, China.
}

\begin{tabular}{|c|c|}
\hline \multicolumn{2}{|l|}{ Article Info } \\
\hline Received: & 17 April 2016 \\
\hline Accepted: & 24 April 2016 \\
\hline Available Online: & 16 October 2016 \\
\hline \multicolumn{2}{|c|}{ DOI: 10.3329/bjp.v11i4.27384 } \\
\hline \multicolumn{2}{|c|}{$\begin{array}{l}\text { Cite this article: } \\
\text { Liang Q, Fu Q, Li W, You J, Zhao Z. } \\
\text { Lapatinib, trastuzumab or the combi- } \\
\text { nation added to neoadjuvant chemo- } \\
\text { therapy for breast cancer. Bangladesh } \\
\text { J Pharmacol. 2016; } 11: 863-68 \text {. }\end{array}$} \\
\hline
\end{tabular}

\begin{abstract}
The aim of this study was to compare the efficacy and safety of trastuzumab versus the combination of trastuzumab and lapatinib added to neoadjuvant chemotherapy for HER2 positive breast cancer. PubMed, MEDLINE, The Cochrane Library, Web of Science and nearly 5 years of the important international conference on oncology records were searched for randomized clinical trials that compared lapatinib plus trastuzumab and neoadjuvant chemotherapy (NAC) with trastuzumab in combination with NAC and that included pathologic complete response rate as the primary outcome. Finally, 6 clinical randomized controlled trials were included. Meta-analysis shows that pathological complete response rate was signifi-cantly increased in trastuzumab plus lapatinib group than single use trastuzumab group (53.4\%, 40.4\%, $\mathrm{RR}=1.75,95 \% \mathrm{CI} 1.38 \sim 2.23, \mathrm{p}<0.001)$. In conclusion, the combination of trastuzumab and lapatinib added to neoadjuvant chemotherapy in HER2-positive breast cancer is more effective.
\end{abstract}

\section{Introduction}

With the application of the trastuzumab which is the first target drug for human epidermal growth factor receptor 2 molecular, overall survival in patients with HER2-positive breast cancer has been significantly improved (Ross et al., 2009; Dawood et al., 2009). Trastuzumab in breast cancer neoadjuvant therapy (Gianni et al., 2011) and adjuvant therapy (Viani et al., 2007) and metastasis of breast cancer (Harris et al., 2011) can make patients benefit from this has now been confirmed.

In terms of survival and overall disease progression, neoadjuvant chemotherapy for the treatment of breast cancer has been reported to be equivalent to adjuvant chemotherapy (Mauri et al., 2005). Besides, neoadjuvant chemotherapy offers certain benefits, since it can decrease the primary tumor in the majority of patients, increasing breast-conserving surgery (BCS) rates or improving respectability (Huang et al., 2009). Lapatinib as the second listed anti-HER2 target drug is combined with capecitabine, this has become the standard first-line treatment of advanced HER2positive metastatic breast cancer patients (Geyer et al., 2006). For HER2 over-expressing breast cancer, preoperatively given target of anti-HER2 treatment can significantly inhibit the proliferation of tumor, reduce tumor residual after treatment and increase the probability of breast conserving surgery and improve resectability and for evaluation of tumor response to chemotherapy by changes in tumor size (Jackisch et al., 2015; Gianni et al., 2014; Badwe et al., 2011).

Given the promising results of trials that evaluated the addition of lapatinib to trastuzumab in metastatic disease (Blackwell et al., 2012), multiple studies have been aimed at evaluating the clinical benefit of adding lapatinib to trastuzumab plus chemotherapy for operable HER2-positive breast cancer in neoadjuvant 
settings; results have been conflicting. So, to evaluate the efficacy of adding lapatinib to trastuzumab combined with neoadjuvant therapy for the treatment of HER2-positive breast cancer, a meta-analysis of all relevant published randomized clinical trials (RCTs) was performed.

\section{Materials and Methods}

\section{Eligibility criteria}

Have been published regarding the use of patients with HER2-positive breast cancer neoadjuvant chemotherapy combined with trastuzumab compared neoadjuvant chemotherapy combined with trastuzumab, lapatinib dual targeting drug efficacy and safety of stage II or III prospective random control research. The test group was neoadjuvant chemotherapy plus trastuzumab plus lapatinib. The control group was neoadjuvant chemotherapy plus trastuzumab. There was no restriction on neoadjuvant chemotherapy, but for the same study, the test group and the control group were the same as the new adjuvant chemotherapy, only anti-HER2 treatment was different. The primary outcome was a pathological complete response (pCR).

\section{Exclusion criteria}

i) The study of non-operative advanced breast cancer; ii) Non-prospective randomized controlled trial; iii) Baseline balance between the test group and the control group was poor, and they were not comparable between the two groups; iv) Study on the evaluation index of curative effect; v) High rate of loss of followup, more than $10 \%$ of the study; vi) The follow-up study was less than 2 years.

\section{Search strategy}

Computer retrieval PubMed, Medline, The Cochrane Library, Web of Science, Chinese journal full-text database and Wan Fang Medical journal full-text database, plus nearly 5 years of the important international conference on oncology records retrieval time was limited up to July in 2015. The language was not limited. When the same research had a number of literature reports, only the latest and most recent literature was evaluated. Key words were breast cancer, neoadjuvant, trastuzumab and lapatinib, breast cancer, neoadjuvant chemotherapy and according to the reference literature expand the search.

\section{Data extraction}

By two researchers independently, encounter differences through discussion, access to the original data or consult the relevant experts to solve. Data extraction includes: The first author's name, year of publication, the number of cases could be evaluated the efficacy of intervention measures, and indicators, etc.

\section{Quality control}

To assess the validity of the included studies, according to the Cochrane handbook, we examined the sequence generation of allocation, allocation concealment, masking of participants, personnel and outcome assessors, incomplete outcome data, selective outcome reporting.

\section{Statistical analysis}

Meta software RevMan 5.0 was used for statistical analysis. For each included study, we will calculate risk ratio (RR) and 95\% confidence intervals (95\% confidence interval, 95\% CI). The Q-statistic was used to test heterogeneity between trials. The presence of statistical heterogeneity was assessed using Cochran's Q test and quantified using $\mathrm{I}^{2}$ and respective $95 \%$ CI. p $<0.10$ was considered to indicate a statistically significant difference. For the $\mathrm{I}^{2}$ values, $\geq 50 \%$ indicated a large heterogeneity. No obvious heterogeneity across studies using random effects model, the Mantel-Haenszel metaanalysis; obvious heterogeneity exists, the first analysis of heterogeneity produces the reason, after treatment, the heterogeneity can't be eliminated, we will use subgroup analysis.

\section{Results}

\section{Literature selection and study characteristics}

The process of identifying eligible trials is presented in Figure 1. According to the above retrieval strategy initially obtained 476 articles, after eliminating duplicate documents retained 450 . By reading the title and abstract, excluding the review, case report, retrospective study, observational studies and intervention measures did not meet the inclusion criteria of literature and 30 articles. Six eligible full-text articles were retrieved, all of which were randomized controlled trials and from peer-reviewed studies. These trials were included in the meta-analysis. The basic characteristics of the 6 trials included are shown in Table I. The assessment of the quality of each study is shown in Table II.

\section{The results of meta-analysis}

A total of 1143 patients $(n=574$, in the lapatinib plus trastuzumab arm and $n=569$, in the trastuzumab arm) from 6 studies (13-18) were analyzed for the effect of adding lapatinib to trastuzumab plus NAC on the pCR rate in breast cancer. The absolute $\mathrm{pCR}$ rate was estimated to be $40.4 \%$ in the trastuzumab alone arm and $53.4 \%$ in the combination arm using random-effects meta-analysis modeling. The odds of pCR in the breast were 1.75 times higher for the combination arm $(95 \%$ CI: $1.38-2.23 ; \mathrm{p}<0.00001$; heterogeneity test: $\mathrm{p}=0.74 ; \mathrm{I}^{2}=$ $0 \%$ ) (Figure 2). 


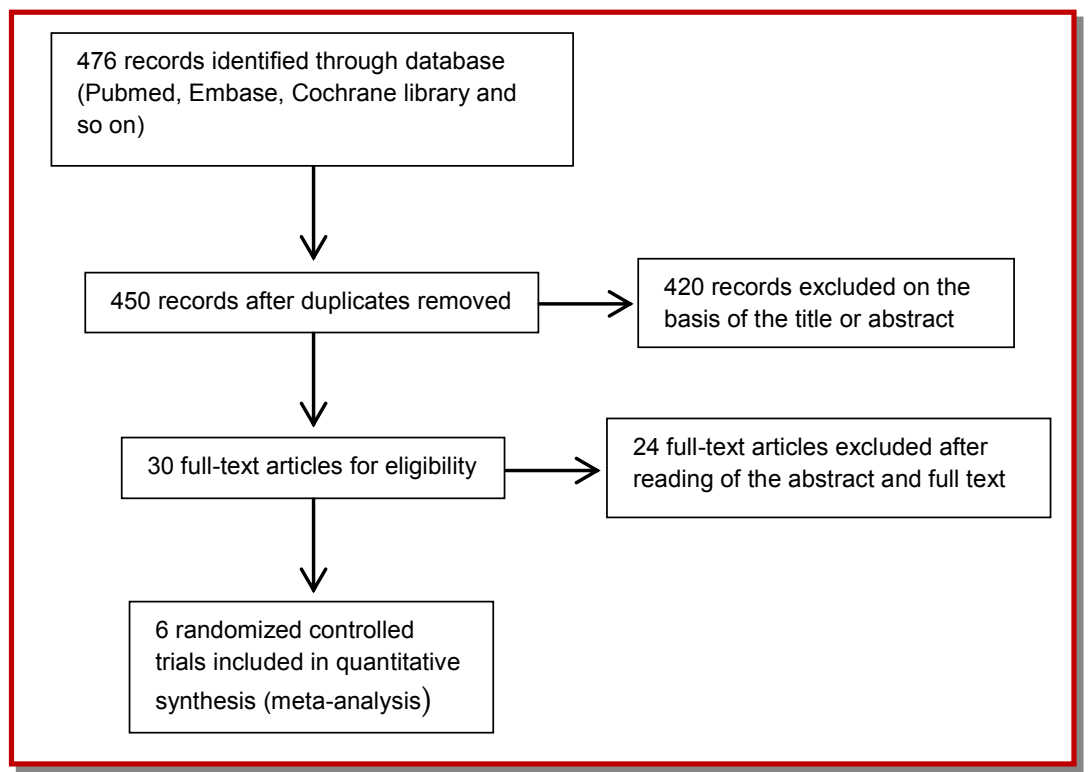

Figure 1: Flow-chart diagram of study selection. Finally, six eligible full-text articles were retrieved

\begin{tabular}{|c|c|c|c|c|c|}
\hline \multicolumn{6}{|c|}{ Table I } \\
\hline \multicolumn{6}{|c|}{ Characteristics of eligible trials } \\
\hline $\begin{array}{l}\text { Clinical trial } \\
\text { (reference) }\end{array}$ & $\begin{array}{l}\text { Number of } \\
\text { patients, } n\end{array}$ & $\begin{array}{l}\text { HER2 status } \\
\text { assessment }\end{array}$ & $\begin{array}{l}\text { Neoadjuvant chemother- } \\
\text { apy duration (week) }\end{array}$ & $\begin{array}{l}\text { Participants } \\
\text { enrolled (n) }\end{array}$ & Neoadjuvant anti-HER2 therapy \\
\hline $\begin{array}{l}\text { CHER-LOB } \\
\text { (Guarneri et } \\
\text { al., 2012) }\end{array}$ & 121 & $\begin{array}{l}\text { IHC(3+) OR } \\
\text { FISH(+) }\end{array}$ & 26 & $\begin{array}{l}39 \\
36 \\
46\end{array}$ & $\begin{array}{l}\mathrm{L} 1500 \mathrm{mg} / \mathrm{d} \\
\mathrm{T} 4 \mathrm{mg} / \mathrm{kg} / \mathrm{w} \rightarrow 2 \mathrm{mg} / \mathrm{kg} / \mathrm{w} \\
\mathrm{L} 1000 \mathrm{mg} / \mathrm{d}+\mathrm{T} 2 \mathrm{mg} / \mathrm{kg} / \mathrm{w}\end{array}$ \\
\hline $\begin{array}{l}\text { NCT } 00524303 \\
\text { (Holmes et al., } \\
\text { 2013) }\end{array}$ & 100 & $\begin{array}{l}\mathrm{IHC}(3+) \text { OR } \\
\operatorname{FISH}(+)\end{array}$ & 26 & $\begin{array}{l}34 \\
33 \\
33\end{array}$ & $\begin{array}{l}\mathrm{L} 1250 \mathrm{mg} / \mathrm{d} \\
\mathrm{T} 4 \mathrm{mg} / \mathrm{kg} / \mathrm{w} \rightarrow 2 \mathrm{mg} / \mathrm{kg} / \mathrm{w} \\
\mathrm{L} 750 \mathrm{mg} / \mathrm{d} \\
+\mathrm{T} 2 \mathrm{mg} / \mathrm{kg} / \mathrm{w}\end{array}$ \\
\hline $\begin{array}{l}\text { Neo ALTTO } \\
\text { (de Azambuja } \\
\text { et al., 2014) }\end{array}$ & 455 & $\begin{array}{l}\mathrm{IHC}(3+) \text { OR } \\
\operatorname{FISH}(+)\end{array}$ & 18 & $\begin{array}{l}154 \\
149 \\
152\end{array}$ & $\begin{array}{l}\mathrm{L} 1500 \mathrm{mg} / \mathrm{d} \\
\mathrm{T} 4 \mathrm{mg} / \mathrm{kg} / \mathrm{w} \rightarrow 2 \mathrm{mg} / \mathrm{kg} / \mathrm{w} \\
\mathrm{L} 1000 \mathrm{mg} / \mathrm{d}+\mathrm{T} 2 \mathrm{mg} / \mathrm{kg} / \mathrm{w}\end{array}$ \\
\hline $\begin{array}{l}\text { NSABP-41 } \\
\text { (Robidoux et } \\
\text { al., 2013) }\end{array}$ & 524 & $\begin{array}{l}\mathrm{IHC}(3+) \text { OR } \\
\mathrm{FISH}(+)\end{array}$ & 12 & $\begin{array}{l}173 \\
178 \\
173\end{array}$ & $\begin{array}{l}\mathrm{L} 1250 \mathrm{mg} / \mathrm{d} \\
\mathrm{T} 4 \mathrm{mg} / \mathrm{kg} / \mathrm{w} \rightarrow 2 \mathrm{mg} / \mathrm{kg} / \mathrm{w} \\
\mathrm{L} 750 \mathrm{mg} / \mathrm{d} \\
+\mathrm{T} 2 \mathrm{mg} / \mathrm{kg} / \mathrm{w}\end{array}$ \\
\hline $\begin{array}{l}\text { CALGB40601 } \\
\text { (Carey et al., } \\
\text { 2013) }\end{array}$ & 305 & $\begin{array}{l}\mathrm{IHC}(3+) \mathrm{OR} \\
\mathrm{FISH}(+)\end{array}$ & 16 & $\begin{array}{r}67 \\
120 \\
118\end{array}$ & $\begin{array}{l}\mathrm{L} 1500 \mathrm{mg} / \mathrm{d} \\
\mathrm{T} 4 \mathrm{mg} / \mathrm{kg} / \mathrm{w} \rightarrow 2 \mathrm{mg} / \mathrm{kg} / \mathrm{w} \\
\mathrm{L} 750 \mathrm{mg} / \mathrm{d} \\
+\mathrm{T} 2 \mathrm{mg} / \mathrm{kg} / \mathrm{w}\end{array}$ \\
\hline $\begin{array}{l}\text { EORTC10054 } \\
\text { (Bonnefoi et } \\
\text { al., 2015) }\end{array}$ & 128 & $\begin{array}{l}\mathrm{IHC}(3+) \mathrm{OR} \\
\mathrm{FISH}(+)\end{array}$ & 18 & $\begin{array}{l}23 \\
53 \\
52\end{array}$ & $\begin{array}{l}\mathrm{L} 1000 \mathrm{mg} / \mathrm{d} \\
\mathrm{T} 4 \mathrm{mg} / \mathrm{kg} / \mathrm{w} \rightarrow 2 \mathrm{mg} / \mathrm{kg} / \mathrm{w} \\
\mathrm{L} 1000 \mathrm{mg} / \mathrm{d}+\mathrm{T} 2 \mathrm{mg} / \mathrm{kg} / \mathrm{w}\end{array}$ \\
\hline
\end{tabular}

\section{Discussion}

HER2 amplification in breast cancer is a classic example of oncogene addiction in solid tumor oncology (Olson, 2012). Recent studies suggest that dual HER2 inhibition (the administration of two anti-HER2 therapeutics simultaneously) may induce more durable tumor responses than sequential HER2 specific monotherapy (Blackwell et al., 2010). The study systematically collected HER2-positive breast cancer patients treated with neoadjuvant chemotherapy combined with trastuzumab, lapatinib dual anti-HER2 therapy compared with neoadjuvant chemotherapy plus trastuzumab randomized controlled trial evidence. This evidence support HER2-positive breast cancer treated with neoadjuvant chemotherapy combined with antiHER2 dual targeting drug. Trastuzumab and lapatinib have effects on different parts of the HER2 receptor, 


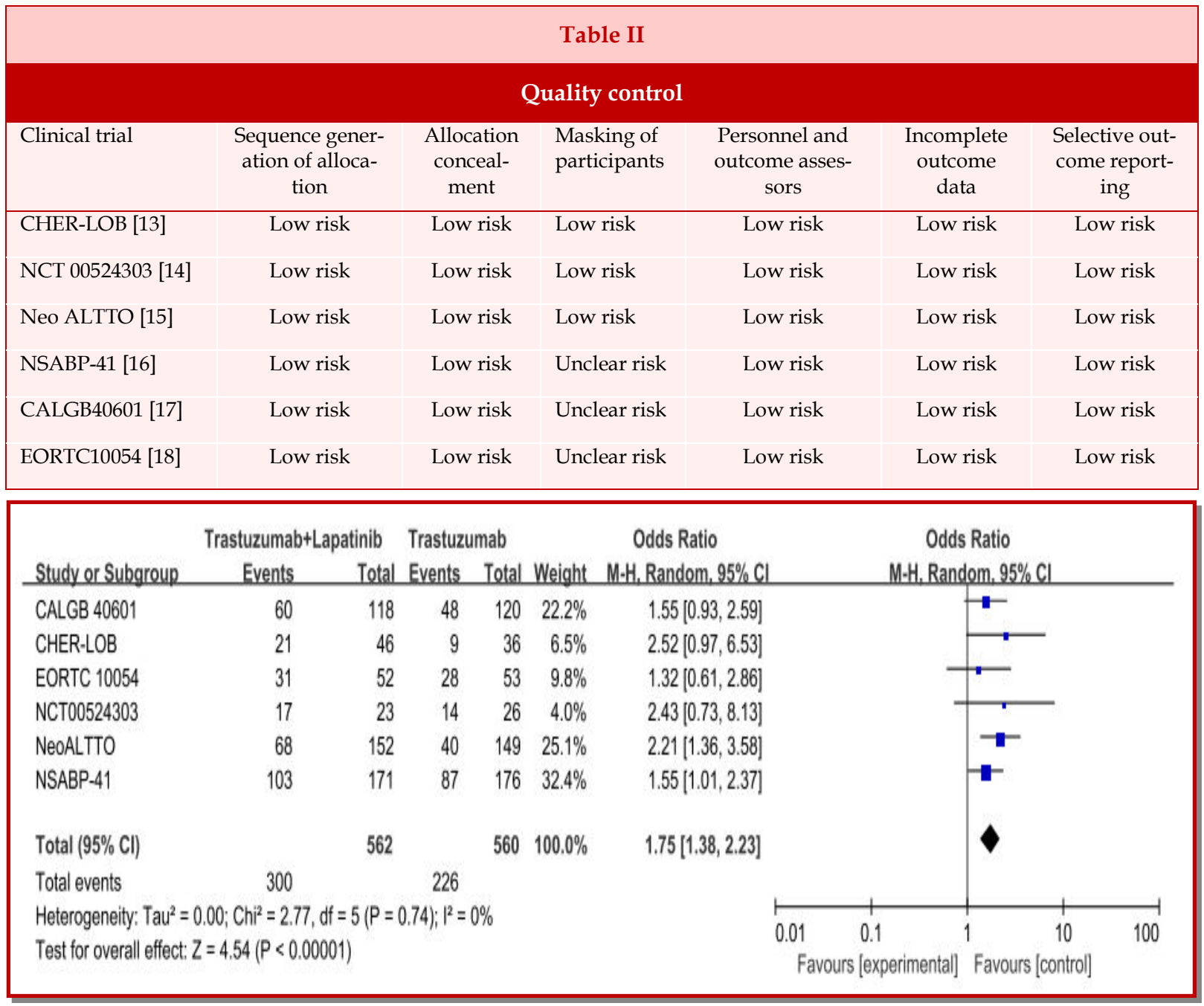

Figure 2: The results of meta-analysis

their principle and mechanism can complement each other, a pre-clinical study has confirmed the combined use of the two drugs can dramatically inhibit the growth of breast cancer cells, enhancement of HER2 blocking effect (Konecny et al., 2006). In addition, more thorough and more comprehensive anti-HER2 therapy seems to reduce the resistance of HER2 (Wang et al., 2011). That trastuzumab, lapatinib double anti-HER2 drugs cure HER2-positive metastatic breast cancer, which have been confirmed in clinical therapy (Blackwell et al., 2012). Pertuzumab and trastuzumab are complementary in the anti-HER2 mechanism, which is same as lapatinib. Combination pertuzumab with trastuzumab for the first-line treatment of HER2positive metastatic breast cancer is very effective, which has been confirmed in clinical therapy too (Baselga et al., 2012). The meta-analysis also has some limitations. Firstly, the relatively small number of the case in the study may affect the statistical conclusion. But in order to be able to collect all randomized controlled trials, the author has systematically screened all the possible candidates for randomized controlled study. Secondly, due to the inability to get the survival data in the case of, we are not able to assess the higher $\mathrm{pCR}$ rate patients whether have longer survival in the study. However, pCR as independent prognostic factors of survival benefit, this has been confirmed on HER2positive breast cancer patients after anti-HER2 therapy (Doval et al., 2013; Untch et al., 2011). Neoadjuvant studies using anti-HER2 agents have revealed that the pCR rate is correlated with disease-free survival (Gianni et al., 2010; Untch et al., 2011).

\section{Conclusion}

This study demonstrates that the use of trastuzumab in the neoadjuvant therapy combined with lapatinib dual targeting of anti-HER2 therapy can significantly increase the pCR rate in the HER2-positive breast cancer patients. But a combination of targeted drugs in the double neoadjuvant treatment of HER2-positive 
breast cancer can take advantage of $\mathrm{pCR}$ to prolong disease-free survival or overall survival, still need further verification.

\section{References}

de Azambuja E, Holmes AP, Piccart-Gebhart M, Holmes E, Di Cosimo S, Swaby RF, Untch M, Jackisch C, Lang I, Smith I, Boyle F, Xu B, Barrios CH, Perez EA, Azim HA Jr, Kim SB, Kuemmel S, Huang CS, Vuylsteke P, Hsieh RK, Gorbunova V, Eniu A, Dreosti L, Tavartkiladze N, Gelber RD, Eidtmann H, Baselga J. Lapatinib with trastuzumab for HER2-positive early breast cancer (NeoALTTO): Survival outcomes of a randomised, open-label, multicentre, phase 3 trial and their association with pathological complete response. Lancet Oncol. 2014; 15: 1137-46.

Badwe R, Hawaldar R, Parmar V, Nadkarni M, Shet T, Desai S, Gupta S, Jalali R, Vanmali V, Dikshit R, Mittra I. Singleinjection depot progesterone before surgery and survival in women with operable breast cancer: A randomized controlled trial. J Clin Oncol. 2011; 29: 2845-51.

Baselga J, Cortés J, Kim SB, Im SA, Hegg R, Im YH, Roman L, Pedrini JL, Pienkowski T, Knott A, Clark E, Benyunes MC, Ross G, Swain SM, CLEOPATRA Study Group. Pertuzumab plus trastuzumab plus docetaxel for metastatic breast cancer. N Engl J Med. 2012; 366: 109-19.

Blackwell KL, Burstein HJ, Storniolo AM, Rugo H, Sledge G, Koehler M, Ellis C, Casey M, Vukelja S, Bischoff J, Baselga J, O'Shaughnessy J. Randomized study of lapatinib alone or in combination with trastuzumab in women with ErbB2positive, trastuzumab-refractory metastatic breast cancer. J Clin Oncol. 2010; 28: 1124-30.

Blackwell KL, Burstein HJ, Storniolo AM, Rugo HS, Sledge G, Aktan G, Ellis C, Florance A, Vukelja S, Bischoff J, Baselga J, O'Shaughnessy J. Overall survival benefit with lapatinib in combination with trastuzumab for patients with human epidermal growth factor receptor 2-positive metastatic breast cancer: Final results from the EGF104900 study. J Clin Oncol. 2012; 30: 2585-92.

Bonnefoi H, Jacot W, Saghatchian M, Moldovan C, VenatBouvet L, Zaman K, Matos E, Petit T, Bodmer A, QuenelTueux N, Chakiba C, Vuylsteke P, Jerusalem G, Brain E, Tredan O, Messina CG, Slaets L, Cameron D. Neoadjuvant treatment with docetaxel plus lapatinib, trastuzumab, or both followed by an anthracycline-based chemotherapy in HER2-positive breast cancer: Results of the randomised phase II EORTC 10054 study. Ann Oncol. 2015; 26: 325-32.

Carey LA, Berry DA, Ollila D, Harris L, Krop IE, Weckstein D, Henry NL, Anders CK, Cirrincione C, Winer EP. Clinical and translational results of CALGB 40601: A neoadjuvant phase III trial of weekly paclitaxel and trastuzumab with or without lapatinib for HER2-positive breast cancer. J Clin Oncol. 2013; 31.

Dawood S, Broglio K, Buzdar AU, Hortobagyi GN, Giordano $\mathrm{SH}$. Prognosis of women with metastatic breast cancer by HER2 status and trastuzumab treatment: An institutionalbased review. J Clin Oncol. 2009; 28: 92-98.

Doval DC, Dutta K, Batra U, Talwar V. Neoadjuvant chemotherapy in breast cancer: Review of literature. J Indian Med
Assoc. 2013; 111: 629-31.

Geyer CE, Forster J, Lindquist D, Chan S, Romieu CG, Pienkowski T, Jagiello-Gruszfeld A, Crown J, Chan A, Kaufman B, Skarlos D, Campone M, Davidson, Berger M, Oliva C, Rubin SD, Stein S, Cameron D. Lapatinib plus capecitabine for HER2-positive advanced breast cancer. N Engl J Med. 2006; 355: 2733-43.

Gianni L, Dafni U, Gelber RD, Azambuja E, Muehlbauer S, Goldhirsch A, Untch M, Smith I, Baselga J, Jackisch C. Treatment with trastuzumab for 1 year after adjuvant chemotherapy in patients with HER2-positive early breast cancer: A 4-year follow-up of a randomised controlled trial. Lancet Oncol. 2011; 12: 236-44.

Gianni L, Eiermann W, Semiglazov V, Lluch A, Tjulandin S, Zambetti M, Moliterni A, Vazquez F, Byakhov MJ, Lichinitser M, Climent MA, Ciruelos E, Ojeda B, Mansutti M, Bozhok A, Magazzù D, Heinzmann D, Steinseifer J, Valagussa P, Baselga J. Neoadjuvant and adjuvant trastuzumab in patients with HER2-positive locally advanced breast cancer (NOAH): Follow-up of a randomised controlled superiority trial with a parallel HER2-negative cohort. Lancet Oncol. 2014; 15: 640-47.

Gianni L, Eiermann W, Semiglazov V, Manikhas A, Lluch A, Tjulandin S, Zambetti M, Vazquez F, Byakhow M, Lichinitser M Cameron D, Mano M, Luiz Pedrini J, Veronesi A, Mendiola C, Pluzanska A, Semiglazov V, Vrdoljak E, Eckart MJ, Shen Z, Skiadopoulos G, Procter M, Pritchard KI, Piccart-Gebhart MJ, Bell R. Neoadjuvant chemotherapy with trastuzumab followed by adjuvant trastuzumab versus neoadjuvant chemotherapy alone, in patients with HER2positive locally advanced breast cancer (the NOAH trial): A randomised controlled superiority trial with a parallel HER2 -negative cohort. Lancet 2010; 375: 377-84.

Guarneri V, Frassoldati A, Bottini A, Cagossi K, Bisagni G, Sarti S, Ravaioli A, Cavanna L, Giardina G, Musolino A, Untch M, Orlando L, Artioli F, Boni C, Generali DG, Piacentini F. Preoperative chemotherapy plus trastuzumab, lapatinib, or both in human epidermal growth factor receptor 2-positive operable breast cancer: Results of the randomized phase II CHER-LOB study. J Clin Oncol. 2012; 30: 1989-95.

Harris CA, Ward RL, Dobbins TA, Drew AK, Pearson S. The efficacy of HER2-targeted agents in metastatic breast cancer: A meta-analysis. Ann Oncol. 2011; 22: 1308-17.

Holmes FA, Espina V, Liotta LA, Nagarwala YM, Danso M, Mcintyre KJ, Osborne CRC, Anderson T, Krekow L, Blum JL. Pathologic complete response after preoperative anti-HER2 therapy correlates with alterations in PTEN, FOXO, phosphorylated Stat5, and autophagy protein signaling. BMC Res Notes. 2013; 6: 507.

Huang O, Chen C, Wu J, Chen S, Chen X, Liu G, Hu Z, Lu J, Wu J, Shao Z, Shen Z, Shen K. Retrospective analysis of 119 Chinese non-inflammatory locally advanced breast cancer cases treated with intravenous combination of vinorelbine and epirubicin as a neoadjuvant chemotherapy: A median follow-up of 63.4 months. BMC Cancer. 2009; 9: 1-11.

Jackisch C, Scappaticci FA, Heinzmann D, Bisordi F, Schreitmüller T, von Minckwitz G, Cortés J. Neoadjuvant breast cancer treatment as a sensitive setting for trastuzumab 
biosimilar development and extrapolation. Future Oncol. 2015; 11: 61-71.

Konecny GE, Pegram MD, Venkatesan N, Finn R, Yang G, Rahmeh M, Untch M, Rusnak DW, Spehar G, Mullin RJ, Keith BR, Gilmer TM, Berger M, Podratz KC, Slamon DJ. Activity of the dual kinase inhibitor lapatinib (GW572016) against HER-2-overexpressing and trastuzumab-treated breast cancer cells. Cancer Res. 2006; 66: 1630-39.

Mauri D, Pavlidis N, Ioannidis JP. Neoadjuvant versus adjuvant systemic treatment in breast cancer: A meta-analysis. J Natl Cancer Inst. 2005; 97: 188-94.

Olson EM. Maximizing human epidermal growth factor receptor 2 inhibition: A new oncologic paradigm in the era of targeted therapy. J Clin Oncol. 2012; 30: 1712-14.

Robidoux A, Tang G, Rastogi P, Geyer CE Jr, Azar CA, Atkins JN, Fehrenbacher L, Bear HD, Baez-Diaz L, Sarwar S, Margolese RG, Farrar WB, Brufsky AM, Shibata HR, Bandos H, Paik S, Costantino JP, Swain SM, Mamounas EP, Wolmark N. Lapatinib as a component of neoadjuvant therapy for HER2-positive operable breast cancer (NSABP protocol B-41): An open-label, randomized phase 3 trial. Lancet Oncol. 2013; 14: 1183-92.
Ross JS, Slodkowska EA, Symmans WF, Pusztai L, Ravdin PM, Hortobagyi GN. The HER-2 receptor and breast cancer: Ten years of targeted anti-HER-2 therapy and personalized medicine. Oncologist 2009; 14: 320-68.

Untch M, Fasching PA, Konecny GE, Hasmüller S, Lebeau A, Kreienberg R, Camara O, Müller V, du Bois A, Kühn T, Stickeler E, Harbeck N, Höss C, Kahlert S, Beck T, Fett W, Mehta KM, von Minckwitz G, Loibl S. Pathologic complete response after neoadjuvant chemotherapy plus trastuzumab predicts favorable survival in human epidermal growth factor receptor 2-overexpressing breast cancer: Results from the TECHNO trial of the AGO and GBG study groups. J Clin Oncol. 2011; 29: 3351-57.

Viani GA, Afonso SL, Stefano EJ, De Fendi LI, Soares FV. Adjuvant trastuzumab in the treatment of HER-2-positive early breast cancer: A meta-analysis of published randomized trials. BMC Cancer. 2007; 7: 153.

Wang YC, Morrison G, Gillihan R, Guo J, Ward RM, Fu X, Botero MF, Healy NA, Hilsenbeck SG, Phillips GL, Chamness GC, Rimawi MF, Osborne CK, Schiff R. Different mechanisms for resistance to trastuzumab versus lapatinib in HER2-positive breast cancers- role of estrogen receptor and HER2 reactivation. Breast Cancer Res. 2011; 13: R121. 


\section{Your feedback about this paper}

1. Number of times you have read this paper 0

2. Quality of paper Click

3. Your comments

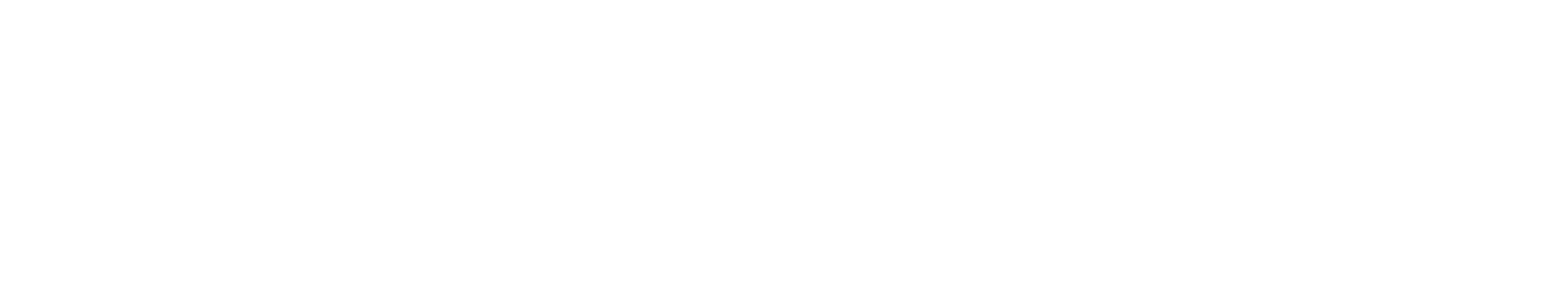

